\title{
PEMANFAATAN LIMBAH TEMPURUNG BIJI PALA SEBAGAI BAHAN BAKAR ALTERNATIF BRIKET ARANG BIOMASSA
}

\author{
Ariviana Lientje Kakerissa \\ ariviana.kakerissa@fatek.unpatti.ac.id \\ Dosen Jurusan Teknik Industri, Fakultas Teknik, Universitas Pattimura Ambon
}

\begin{abstract}
ABSTRAK
Pemanfaatan pala yang dilakukan masyarakat negeri Booi hanya menyertakan bagian biji dan bunga (fuli) pala saja, sementara daging buah dan tempurung biji palanya dibuang sebagai limbah. Penelitian ini membantu untuk memanfaatkan limbah tempurung biji pala sebagai briket arang yang merupakan salah satu bahan bakar yang berasal dari biomassa. Tujuan penelitian ini adalah membuat Biomassa dari tempurung biji pala sebagai bahan bakar alternatif dan juga untuk mengetahui model serta komposisi briket yang sesuai dengan SNI briket arang. Proses desain dan percobaan briket arang tempurung biji pala meliputi proses pengarangan, pengilingan, pencampuran, pencetakan hingga pengeringan. Pengujian yang dilakukan adalah dengan menggunakan analisis peroksimasi dengan parameter kadar udara, kadar abu dan nilai kalor yang sesuai denga SNI briket arang. Briket arang tempurung biji pala yang diproduksi pada umumnya dapat menghasilkan sifat dan kimia yang lebih baik jika dibandingkan dengan kualitas bahan bakunya. Kadar udara rata-rata berkisar antara $2,11 \%$, kadar abu $7,80 \%$, dan nilai kalor pengukuran antara $5858-7439 \mathrm{kal} / \mathrm{gram}$.
\end{abstract}

Kata Kunci: Tempurung Biji Pala, Briket Arang Biomassa.

\begin{abstract}
The use of nutmeg by Booi's people only included the nutmeg seeds and flowers, while the flesh of the fruit and shell of the seeds was discarded as waste. This research helps to utilize nutmeg shell waste as charcoal briquettes which is one of the fuels derived from biomass. The purpose of this study is to make biomass from nutmeg shells as an alternative fuel and also to determine the model and composition of briquettes that are in accordance with SNI charcoal briquettes. The design process and experiments of nutmeg shell charcoal briquettes include the process of curing, grinding, mixing, molding to drying. Tests carried out are by using peroximation analysis with parameters of air content, ash content and heating value in accordance with SNI charcoal briquettes. Nutmeg shell charcoal briquette briquettes produced in general can produce better properties and chemistry when compared to the quality of raw materials. Average air content ranged from $2.11 \%$, ash content $7.80 \%$, and the heating value of measurements between 5858 $7439 \mathrm{cal} / \mathrm{gram}$.
\end{abstract}

Keywords: Nutmeg Shell Shell, Biomass Charcoal Briquette.

\section{PENDAHULUAN}

Tanaman Pala merupakan salah satu dari beberapa komoditi unggulan pertanian yang dapat dikembangkan. Luas areal perkebunan pala di Maluku sebesar 28.864 HA. Besaran tersebut mengisyaratkan bahwa pala memiliki potensi untuk dikembangkan menjadi produk unggulan dan turunannya.

Pemanfaatan tanaman pala di negeri Booi dari waktu ke waktu hanya meliputi biji dan fuli pala sedangkan daging buah, tempurung maupun daun pala tidak dimanfaatkan oleh masyarakat. Luas areal perkebunan pala di negeri Booi adalah 13 
HA dengan jumlah pohon pala sekitar 1274 pohon. Kapasitas panen buah pala adalah 9001200 buah pala gelondongan (utuh) per pohon atau $37,5-50 \mathrm{Kg}$ [1]. Dalam setahun terdapat 3 kali musim panen, sehingga kapasitas panen buah pala dalam setahun adalah $120 \mathrm{Kg} /$ pohon. Dengan kondisi ini, dapat diperkirakan kapasitas panen buah pala negeri Booi adalah sebanyak 152,880 Kg atau 152,88 ton per tahun. [2]. Dari jumlah ini, maka banyaknya tempurung biji pala yang terbuang adalah 3,96\% dari kapasitas panen yaitu 6,81 ton per tahun.

Penelitian ini dilakukan sebagai upaya pemanfaatan tempurung biji pala yang merupakan limbah bagi masyarakat negeri Booi untuk memberikan nilai tambah, meningkatkan kesempatan kerja dan meningkatkan pendapatan petani, mengingat bagian buah pala yang dimanfaatkan masyarakat setempat hanya bagian biji dan fulinya saja. Tujuan utama penelitian ini adalah mendesain tempurung biji pala menjadi briket arang biomassa sebagai bahan bakar alternatif, serta menguji efektifitas dari tiap model yang didesain.

\section{KAJIAN TEORI DAN METODE}

\subsection{Pala}

Buah pala terdiri dari empat bagian yaitu daging buah, fuli, tempurung dan biji. Buah pala dan fuli merupakan dua produk besar dari tanaman pala dan diketahui sebagai rempah. Seluruh bagian dari buah pala dapat dimanfaatkan untuk berbagai keperluan seperti dijadikan rempah dan minyak pala yang bisa digunakan sebagai obatobatan. Daging buah memiliki presentase lebih besar dibandingkan dengan bagian yang lain.

Tabel 1. Persentase berat dari bagian buah pala

\begin{tabular}{lcc}
\hline Bagian buah & $\begin{array}{c}\text { Persentase } \\
\text { basah }(\%)\end{array}$ & $\begin{array}{c}\text { Persentase } \\
\text { kering angin } \\
(\%)\end{array}$ \\
\hline Daging & 77,8 & 9,93 \\
Fuli & 4 & 2,09 \\
Tempurung & 5,1 & - \\
Biji & 13,1 & 8,4 \\
\hline
\end{tabular}

Sumber Data: [3]

\subsection{Briket}

Briket merupakan bahan bakar alternatif yang menyerupai arang dan memiliki kerapatan yang lebih tinggi. Sebagai salah satu bentuk bahan bakar baru, briket merupakan bahan yang sederhana, baik dalam proses pembuatan ataupun dari segi bahan baku yang digunakan, sehingga bahan bakar briket memiliki potensi yang cukup besar untuk dikembangkan. Pembuatan briket telah banyak dilakukan dengan menggunakan bahan yang berbasis biomassa, seperti briket serbuk gergaji kayu [4]. Berikut dapat dilihat standar kualitas briket dari beberapa negara :

Tabel 2. Standar kualitas briket arang Beberapa Negara

\begin{tabular}{lccccc}
\hline \multirow{2}{*}{$\begin{array}{l}\text { Sifat- } \\
\text { sifat }\end{array}$} & \multicolumn{5}{c}{ Standar Mutu } \\
\cline { 2 - 6 } & r & $\begin{array}{l}\text { Jepan } \\
\text { g }\end{array}$ & $\begin{array}{l}\text { Inggri } \\
\text { s }\end{array}$ & $\begin{array}{l}\text { US } \\
\text { A }\end{array}$ & SNI \\
\hline $\begin{array}{l}\text { Kadar } \\
\text { Air \% }\end{array}$ & $6-8$ & $6-8$ & $3-4$ & 6 & 8 \\
Kadar & $3-6$ & $3-6$ & 10 & 18 & 8 \\
$\begin{array}{l}\text { Abu } \% \\
\text { Fixed }\end{array}$ & $60-80$ & $60-80$ & 75 & 58 & \\
Carbo & & & & & \\
n \% & & & & & \\
Nilai & 6000 & 6000 & 7300 & 650 & 500 \\
Kalor & s/d & s/d & & 0 & 0 \\
kal/g & 7000 & 7000 & & & \\
\hline
\end{tabular}

Sumber : [5]

\subsection{Briket Arang}

Briket yang paling umum digunakan adalah briket batu bara, briket arang, briket gambut, dan briket biomassa. B ahan biomassa yang dapat digunakan untuk pembuatan briket berasal dari :

1. Limbah pengolahan kayu seperti : logging residues, bark, saw dusk, shavinos, waste timber.

2. Limbah pertanian seperti; Batok kelapa, jerami, sekam padi, ampas tebu, daun kering, ampas kayu, tongkol jagung dll.

3. Limbah bahan berserat seperti; serat kapas, goni, sabut kelapa.

4. Limbah pengolahan pangan seperti kulit kacang-kacangan, biji-bijian, kulit- kulitan.

5. Selulosa seperti, limbah kertas, karton.dll [6]. Berdasarkan beberapa jenis bahan biomassa yang dapat dimanfaatkan untuk briket, maka salah satu jenis limbah yang perlu diteliti yaitu Tanaman pala berupa tempurung biji pala (Myristica fragrans Houtt).

\subsection{Syarat-Syarat Briket}

Syarat briket yang baik adalah briket yang permukaannya halus dan tidak meninggalkan bekas hitam di tangan [7]. Selain itu, sebagai 
bahan bakar, briket juga harus memenuhi kriteria sebagai berikut:

1. Mudah dinyalakan.

2. Tidak mengeluarkan asap.

3. Emisi gas hasil pembakaran tidak mengandung racun (Toxit)

4. Kedap air dan hasil pembakaran tidak berjamur bila disimpan pada waktu lama.

5. Menunjukkan upaya laju pembakaran (waktu, laju pembakaran, dan suhu pembakaran) yang baik.

\subsection{Perekat briket}

Perekat adalah suatu zat atau bahan yang memiliki kemampuan untuk mengikat dua benda melalui ikatan permukaan. Beberapa istilah lain dari perekat yang memiliki kekhususan meliputi glue, mucilage, paste, dan cement. Glue merupakan perekat yang terbuat dari protein hewani, seperti kulit, kuku, urat, otot dan tulang yang secara luas digunakan dalam industri pengerjaan kayu. Mucilage adalah perekat yang dipersiapkan dari getah dan air dan diperuntukkan.Terutama untuk perekat kertas. Paste merupakan perekat pati (starch) yang dibuat melalui pemanasan campuran pati dan air serta dipertahankan berbentuk pasta. Cement adalah istilah yang digunakan untuk perekat dengan bahan dasarnya adalah karet dan mengeras melaui pelepasan dengan pelarut [8].

Untuk merekatkan partikel-partikel zat dalam bahan baku pada proses pembuatan briket maka diperlukan zat perekat sehingga dihasilkan briket yang kompak. Berdasarkan fungsi dari perekat dan kualitasnya, pemilihan bahan perekat dapat dibagi sebagai berikut :

1. Berdasarkan sifat/bahan baku perekat briket. Adapun karakteristik bahan baku perekatan untuk pembuatan briket adalah sebagai berikut:

a. Memiliki gaya kohesi yang baik bila dicampur dengan semikokas atau batubara.

b. Mudah terbakar dan tidak berasap.

c. Mudah didapat dalam jumlah banyak dan murah harganya.

d. Tidak mengeluarkan bau, tidak beracun dan tidak berbahaya.

2. Berdasarkan jenis bahan baku perekat Jenis bahan baku yang umum dipakai sebagai pengikat untuk pembuatan briket, yaitu :

a. Pengikat Anorganik

Pengikat anorganik dapat menjaga

ketahanan briket selama proses

pembakaran sehingga dasar

permeabilitas bahan bakar tidak terganggu. Pengikat anorganik ini mempunyai kelemahan yaitu adanya tambahan abu yang berasal dari bahan pengikat sehingga dapat menghambat pembakaran dan menurunkan nilai kalor. Contoh dari pengikat anorganik antara lain semen, lempung (tanah liat), natrium silikat.

b. Pengikat Organik

Pengikat organik menghasilkan abu yang relatif sedikit setelah pembakaran briket dan umumnya merupakan bahan perekat yang efektif. Contoh dari pengikat organik diantaranya kanji, tar, aspal, amilum, molase dan parafin. Adapun bahan perekat dalam pembuatan briket ini adalah tepung tapioka (sagu).

Nilai kalor, stabilitas dan ketahanan briket dapat dipengaruhi oleh pemilihan jenis perekat yang digunakan dalam pembuatan briket. Dalam pemilihan jenis perekat dapat juga memperhatikan nilai kalor dari masing-masing perekat. Nilai kalor masing-masing bahan perekat dapat dilihat pada tabel berikut ini.

Tabel 3. Uji nilai kalor jenis perekat Jenis Perekat Nilai Kalor (kal/g)

\begin{tabular}{ll}
\hline Tapioka & 6332,654 \\
Terigu & 6455,888 \\
Molase & 6106,239 \\
Silikat & 5808,168 \\
\hline
\end{tabular}

Sumber : [9]

\subsection{Metode}

Penelitian dilakukan dengan metode observasi langsung, wawancara, serta studi pustaka. Variabel penelitian dalam penelitian ini adalah variabel terikat dan variable bebas. Variabel terikat meliputi: kadar air (\%), kadar abu (\%), nilai kalor (Kal/g) dan lama nyala api (jam/buah). Sementara variabel bebasnya adalah model briket 
yang dibuat, antara lain : briket model kotak, bulat, bulat telur, segi enam dan silinder.

\section{HASIL DAN PEMBAHASAN}

\subsection{Proses Produksi Briket Tempurung Biji Pala}

\subsubsection{Bahan Baku}

Biji pala yang telah kering kemudian diketok atau dihancurkan guna memisahkan biji dan tempurung,untuk $1 \mathrm{~kg}$ tempurung biji pala dihasilkan dari \pm 400 buah pala atau 2,5 $\mathrm{kg}$ buah pala kering. Tempurung biji pala kering inilah yang akan menjadi bahan baku utama pembuatan briket.

\subsubsection{Pengarangan/karbonisasi}

Pada umumnya suhu yang digunakan pada proses ini sekitar $500-800^{\circ} \mathrm{C}$. Dengan proses karbonisasi zat-zat terbang yang terkandung dalam bahan baku tersebut diturunkan serendah mungkin sehingga produk tersebut tidak berbau dan berasap. Pengarangan dianggap selesai apabila asap yang keluar dari cerobong menipis.

\subsubsection{Penggilingan dan Penyaringan}

Penggilingan diperlukan untuk menghancurkan arang tempurung biji pala yang berukuran besar. Setelah itu dilakukan penyaringan yang berfungsi untuk menyeragamkan bahan baku tempurung biji pala. Permukaan arang tempurung biji pala yang seragam akan mudah menempel dan berikatan satu sama lainnya dengan perekat.

\subsubsection{Pencampuran dengan Bahan Perekat}

Bahan perekat yang digunakan adalah tepung tapioka yang telah melalui proses pemanasan dengan air hingga lunak. Perbandingan antara bahan perekat dan arang tempurung biji pala adalah 1 : 5.Arang yang telah dicampur dengan perekat akan membentuk gumpalan adonan, selanjutnya adonan ditimbang dengan berat 50 gram untuk setiap cetakannya dan dicetak dengan lima bentuk kotak/kubus dengan ukuran $2 \times 2 \times 2.5 \mathrm{~cm}$, bulat, oval, hexagonal $/$ prisma dengan ukuran diameter $1 \mathrm{~cm}$. Panjang $5 \mathrm{~cm}$ dan silinder dengan ukuran yang dengan prisma. Jika semakin banyak perekat yang digunakan, maka briket lebih kuat dan tahan pecah namun memiliki kadar abu yang tinngi.

\subsubsection{Pengeringan}

Proses pengeringan dapat dilakukan dengan dua cara yaitu menjemur briket di bawah sinar matahari dan di oven, proses pertama pengringan dengan sinar matahari dengan temperature $30^{\circ}$ $33^{\circ} \mathrm{c}$ yang berlangsung pada pukul 09:00 - 16.00 sore hari (6 jam penjemuran).Pengeringan dengan oven dilakuakan selama 2.5-3 jam sampai briket kering. Hasil pengeringan briket tempurung biji pala yang dilakukan oleh peneliti menghasilakn briket dengan kadar air $2.11 \%$ (SNI No.1/6235/2000 yaitu maks $\leq 8$ ).

\subsection{Briket Arang}

Briket arang tempurung biji pala yang dihasilkan diuji sifat fisika dan kimia yaitu tahap melakukan uji karakteristik briket untuk mengidentifikasi apakah briket yang dihasilkan berkualitas bagus yang sesuai dengan SNI atau tidak, langkah-langkah pengujian yang dilakukan meliputi kadar abu, kadar air, nilai kalor, lama nyala api, dan laju pembakaran. Data hasil pengujian ditunjukkan pada tabel berikut.

Tabel 4. Perbandingan mutu briket arang tempurung biji pala berdasarkan SNI No.1/6235/2000

\begin{tabular}{|c|c|c|c|c|c|c|c|c|}
\hline \multirow[b]{2}{*}{ No } & \multirow[b]{2}{*}{ Parameter } & \multirow{2}{*}{$\begin{array}{c}\text { SNI } \\
\text { No.1/ } \\
6235 / \\
2000\end{array}$} & \multicolumn{5}{|c|}{ Jenis Briket } & \multirow[b]{2}{*}{ Kesimpulan } \\
\hline & & & Kotak & Bulat & $\begin{array}{l}\text { Bulat } \\
\text { Telur }\end{array}$ & $\begin{array}{c}\text { Segi } \\
\text { Enam }\end{array}$ & $\begin{array}{c}\text { Silin } \\
\text { der }\end{array}$ & \\
\hline 1 & $\begin{array}{c}\text { Kadar Air } \\
(\%)\end{array}$ & $\leq 8$ & 2.11 & 2.11 & 2.11 & 2.11 & 2.11 & $\begin{array}{l}\text { Memenuhi } \\
\text { Standar }\end{array}$ \\
\hline 2 & $\begin{array}{c}\text { Kadar Abu } \\
(\%)\end{array}$ & $\leq 8$ & 7.80 & 7.80 & 7.80 & 7.80 & 7.80 & $\begin{array}{c}\text { Memenuhi } \\
\text { Standar }\end{array}$ \\
\hline 3 & $\begin{array}{c}\text { Kadar } \\
\text { Karbon }(\%)\end{array}$ & $\leq 77$ & - & - & - & - & - & \\
\hline 4 & $\begin{array}{l}\text { Niai Kalor } \\
\text { (Kal/g) }\end{array}$ & $\underset{5000}{\geq}$ & 5858 & 6358 & 6936 & 6427 & 7439 & $\begin{array}{c}\text { Memenuhi } \\
\text { Standar }\end{array}$ \\
\hline 5 & $\begin{array}{c}\text { Lama } \\
\text { nyala api } \\
\text { (jam / } \\
\text { buah) }\end{array}$ & - & 4.04 & $\begin{array}{c}4 . \\
00\end{array}$ & $\begin{array}{l}3 . \\
53\end{array}$ & 3.37 & $\begin{array}{l}3 . \\
32\end{array}$ & 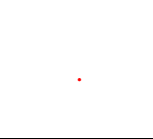 \\
\hline
\end{tabular}

Sumber: [10]

\subsubsection{Pengamatan Karakteristik Briket}

Karakteristik Briket ditentukan oleh kadar air, kadar abu dan nilai kalor yang terkandung di dalam briket tersebut.

\section{a. Kadar Air}

Penetapan kadar air merupakan suatu cara untuk mengukur banyaknya air yang terdapat di dalam briket tempurung biji pala yang telah dibuat. 
Dari hasil pengujian yang didapatkan dari Dinas Kelautan dan Perikanan UPTD Pengujian Mutu Ambon dilakukan tiga kali ulangan. Hasil pertama dengan kadar air sebesar $2.28 \%$, ulangan kedua sebesar $2.03 \%$ dan ulangan ketiga sebesar $2.03 \%$ sehingga total rata-rata kadar air pada briket tempurung biji pala dengan perbandingan $1: 5$ sebesar $2.11 \%$ dari tiga kali pengulangan. Yaitu masih dalam kadar sangat baik berdasarkan standar mutu briket SNI No.1/6235/2000 yaitu Maks $<8 \%$.

\section{b. Kadar Abu}

Pengukuran kadar abu merupakan residu anorganik yang terdapat dalam bahan. Abu dalam bahan ditetapkan dengan menimbang sisa mineral sebagai hasil pembakaran (abu sisa pembakaran) bahan organic pada suhu $500^{\circ} \mathrm{C}$.

Dari hasil pengujian yang didapatkan dari Dinas Kelautan dan Perikanan UPTD Pengujian Mutu Ambon bahwa total rata-rata kadar abu briket tempurung biji pala sebesar $7.80 \%$ dari tiga kali pengulangan. Yaitu masih dalam kadar aman berdasarkan standar mutu briket SNI No.1/6235/2000 yaitu $<8.0 \%$.

\section{c. Nilai Kalor}

Pengukuran nilai kalor (HV) yaitu dengan menimbang sampel dari masing-masing model yang sudah dipisahkan ke dalam cawan besi.

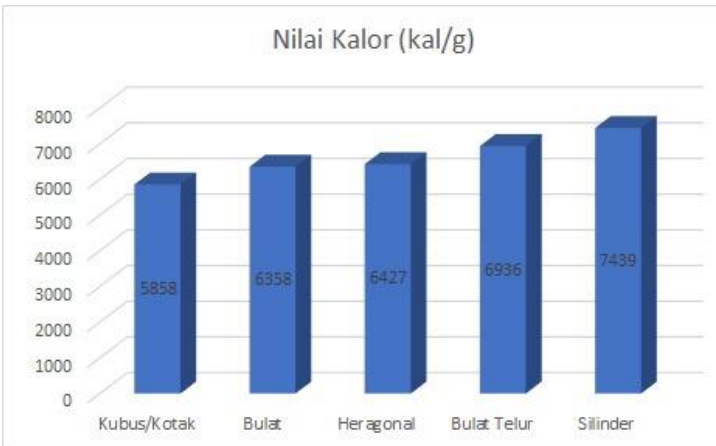

Gambar 1. Grafik antara masing-masing model briket tempurung biji pala terhadap nilai kalor yang dihasilkan

Pada gambar di atas dapat dilihat bahwa terjadi ketidakseimbangan nilai kalor antara model biket satu dengan lainnya yang memberikan pengaruh terhadap kualitas nilai kalor yang dihasilkan. Perbedaan jumlah nilai kalor masing-masing model disebabkan oleh perbedaan akumulasi jumlah nilai kalor yang terkandung pada setiap briket, yang dipengaruhi oleh bentuk susunan briket tempurung biji pala tersebut. Pada model kotak, memiliki nilai kalor terendah yaitu $5858 \mathrm{kal} / \mathrm{g}$ disebabkan karena pada saat pembakaran model ini memenuhi ruang pada tabung bakaran (anglo) sehingga sirkulasi oksigen kurang maksimal. Briket arang dengan model bulat, memiliki nilai kalor $6358 \mathrm{kal} / \mathrm{g}$, model bulat telur memiliki nilai kalor sebesar $6936 \mathrm{kal} / \mathrm{g}$, pada model prisma memiliki nilai kalor sebesar $6427 \mathrm{kal} / \mathrm{g}$, dan model silinder memiliki nilai kalor sebesar $7439 \mathrm{kal} / \mathrm{g}$, model ini memiliki nilai kalor yang paling tinggi karena pada bentuk silinder terdapat lubang panjang pada bagian tengah yang menyerupai silinder yang menyebabkan sirkurlasi udara lancar sehingga bara api yang dihasilkan bertahan lama. Hal ini sesuai dengan literatur Hartoyo (1983), yang menyatakan bahwa model atau bentuk dan kualitas briket mempengaruhi nilai kalor atau energy yang dimiliki bahan penyusunnya. Briket buatan Jepang menghasilkan nilai kalor $6000 \mathrm{kal} / \mathrm{g}$ hingga $7000 \mathrm{kal} / \mathrm{g}$. dan briket buatan Indonesia berdasarkan SNI, yaitu $\geq 5000 \mathrm{kal} / \mathrm{g}$. Nilai kalor rata-rata dalam penelitian ini yaitu $6603.6 \mathrm{kal} / \mathrm{g}$. Hal ini berarti bahwa briket yang dihasilkan memenuhi standar mutu briket SNI dan standar mutu briket buatan Jepang.

\subsubsection{Efektivitas}

Efektivitas yang dimaksud adalah mengukur seberapa lama waktu yang dibutuhkan untuk mendidihkan 1 liter air. Pengukuran dilakukan dengan menggunakan briket tempurung biji pala dengan lima model yang telah dibuat oleh serta menganalisis model mana yang paling efektif selama pembakaran berlangsung.

Tabel 5. Pengukuran rata-rata lama waktu bakar

\begin{tabular}{clcccc}
\hline \multicolumn{5}{c}{$\begin{array}{c}\text { Pengukuran lama waktu yang dibutuhkan } \\
\text { untuk mendidihkan 1 liter air }\end{array}$} \\
\hline No & $\begin{array}{c}\text { Model } \\
\text { Briket }\end{array}$ & $\begin{array}{c}\text { Berat } \\
\text { (gram) }\end{array}$ & $\begin{array}{c}\text { Banyak } \\
\text { Briket } \\
\text { (buah) }\end{array}$ & $\begin{array}{c}\text { Berat Air } \\
\text { yang diuji } \\
\text { (Liter) }\end{array}$ & $\begin{array}{c}\text { Waktu Hasil } \\
\text { Pemanasan } \\
\text { (Menit) }\end{array}$ \\
\hline 1 & Kubus/Kotak & 50 & 5 & 1 & 4.22 \\
2 & Bulat & 50 & 5 & 1 & 4.35 \\
3 & Hexagonal & 50 & 5 & 1 & 4.18 \\
4 & Bulat Telur & 50 & 5 & 1 & 4.22 \\
5 & Silinder & 50 & 5 & 1 & 4.13 \\
\hline
\end{tabular}

Efektivitas daya bakar briket hasil eksperimen pemanasan 1 liter air dari lima model briket arang 
tempurung biji pala hasil cetakan terlihat briket dengan model silinder lebih efektif dalam waktu mendidihkan air selama 4.15 menit.

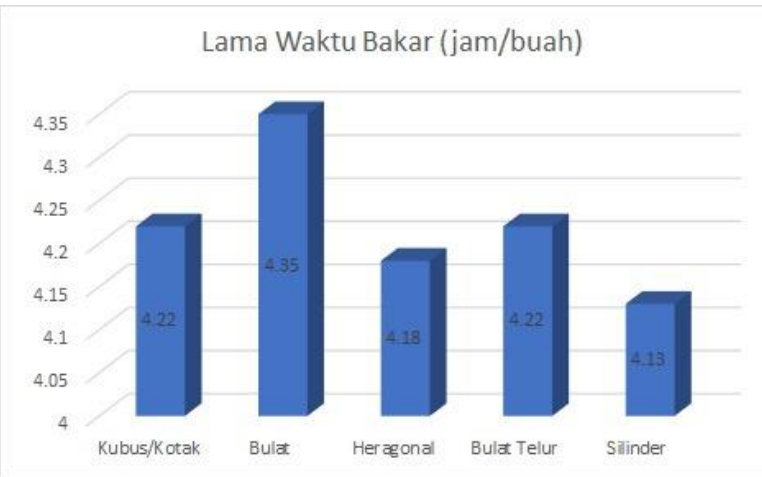

Gambar

2. Waktu yang bibutuhkan untuk mendidihkan $1 \mathrm{Lt}$ Air

Bila diurutkan sesuai lamanya laju pembakaran tiap model briket dapat dilihat pada tabel berikut.

Tabel 6. Laju Pembakaran Tiap Model Briket

\begin{tabular}{ccc}
\hline No & Model Briket & Laju Pembakaran (jam) \\
\hline 1 & Kubus/Kotak & 4,04 \\
2 & Bulat & 4,00 \\
3 & Bulat Telur & 3.53 \\
4 & Hexagonal & 3.37 \\
5 & Silinder & 3.32 \\
\hline
\end{tabular}

Hasil eksperimen laju pembakaran dari kelima model di atas ternyata model yang memiliki lama bakar terpanjang adalah model kotak dengan laju pembakaran selama 4.04 jam dan laju pembakaran tercepat adalah model silinder dengan lama waktu bakar selama 3.32 jam, yaitu terjadi perbedaan waktu 0.72 jam. Perbedaan waktu tersebut disebabkan oleh kemungkinan perolehan oksigen pada masingmasing model.

Sementara Hasil pengukuran dalam mendidihkan 1 liter air dari kelima model diatas ternyata model yang memiliki waktu terlama adalah model bulat dengan waktu pemanasan selama 4 menit 35 detik dan waktu pemanasan tercepat adalah model silinder selama 4 menit 15 detik, yaitu terjadi perbedaan waktu 22 detik. Perbedaan waktu tersebut disebabkan oleh kemungkinan perolehan oksigen pada masingmasing model.

Dari hasil pengukuran waktu dalam mendidihkan 1 liter air dengan waktu tercepat selama 4 menit 15 detik, maka untuk dapat medidihkan air sebanyak 2-5 liter hanya dibutuhkan waktu 8-20 menit. Dengan demikian, briket tempurung biji pala hasil desain ini efektif dapat digunakan untuk berbagai keperluan.

\section{KESIMPULAN}

Hasil penelitian menyimpulkan bahwa :

1. Limbah tempurung biji pala dapat dimanfaatkan sebagai bahan bakar alternatif briket arang biomassa.

2. Pembuatan briket tempurung biji pala dengan perbandingan 1:5 pada arang tempurung biji pala menghasilkan lima desain briket yaitu model kubus/kotak, bulat, hexagonal, bulat telur dan silinder dengan waktu pengarangan di oven selama 2.5 sampai 3 jam.

3. Model yang dinilai paling efektif adalah model silinder yaitu dengan kadar air sebesar $2.11 \%$, kadar abu $7.80 \%$, nilai kalor $7439 \mathrm{kkal} / \mathrm{g}$, laju pembakaran selama 4 jam, 32 menit.

4. Uji efektivitas dalam mendidihkan 1liter air selama 4 menit, 15 detik dinyatakan memenuhi SNI No.1/6235/2000 briket arang, dengan kadar air maks $\leq 8$, kadar abu maks $\leq 8$ dan nilai kalor $\geq 5000$.

5. Berdasarkan analisis proksimasi atau penentuan kadar air, kadar abu, dan nilai kalor, pengujian fisik dan karakteristik serta pengukuran laju pembakaran pada 5 model briket yang dibuat telah sesuai SNI briket arang, sehingga dapat digunakan sebagai bahan bakar alternatif.

\section{DAFTAR PUSTAKA}

[1] Kakerissa Ariviana L. \& Hahury Hendri D., Kearifan Lokal Dalam Pengembangan Industri Rumah Tangga Berbasis Sumberdaya Lokal Kepulauan (Pendekatan One Village One Product-OVOP)., Prosiding Seminar Nasional \& CFP I Ikatan Dosen Republik Indonesia. Hal. 407-421. Ambon 26 Oktober 2017.

[2] Kakerissa Ariviana L., Penentuan Model Pengembangan Agroindustri Pala Melalui Diversifikasi Produk., Jurnal Teknik Industri Universitas Bung Hatta. Volume 6 Nomor 2. Hal. 33-46., 2017.

[3] Nurdjannah Nanan, Teknologi Pengolahan Pala, Badan Penelitian dan Pengembangan Pertanian, Balai Besar Pertanian dan Pengembangan Pascapanen Pertanian, Bogor., 2007. 
[4] Ismayana A., Moh. Rizal A., Pengaruh Jenis dan Kadar Bahan Perekat pada Pembuatan briket Blotong Sebagai Bahan Bakar Alternatif., Jurnal Teknik Industri Pertanian Vol. 21(3), 186-193., (2011).

[5] Mangkau, Andi., dkk., Penelitian Nilai Kalor Briket Tongkol Jagung dengan Berbagai Perbandingan Sekam Padi., Prosiding Hasil Penelitian Fakultas Teknik Unnes ISBN : 978-979-127255-0-6 Vol. 5 Desember 2011.

[6] Patabang D., Studi karakteristik briket arang kulit buah kakao. Jurnal Mekanikal. 1(2): 2331., 2011.

[7] Agung Setiawan, dkk., .Pengaruh Komposisi Pembuatan Biobriket Dari Campuran Kulit Kacang dan Serbuk Gergajian Terhadap Nilai Pembakaran. Jurnal Teknik Kimia, No. 2, Vol. 18., April 2012.

[8] Ruhendi S, Koroh DN, Syamani FA, Yanti H, Nurhaida, Saad S, Sucipto T., Analisis Perekatan Kayu. Bogor : Fakultas Kehutanan, Institut Pertanian Bogor. 2007.

[9] Hanandito, L., \& Willy, S. Pembuatan Briket Arang Tempurung Kelapa Dari Sisa Bahan Bakar Pengasapan Ikan., Semarang., 2011.

[10] Dinas Kelautan dan Perikanan UPTD Pengujian dan Pengolahan Mutu Perikanan Ambon., 2018. 